\title{
Pengembangan Perangkat Pembelajaran Kooperatif Berbasis Gaya Belajar
}

\author{
Muhammad Jarnawi \\ email : i.am.jarnawi@gmail.com \\ Program Studi Pendidikan Fisika FKIP Universitas Tadulako \\ Jl. Soekarno Hatta Km. 9 Kampus Bumi Tadulako Tondo Palu - Sulawesi Tengah
}

\begin{abstract}
Abstrak - Penelitian ini bertujuan untuk mengembangkan perangkat pembelajaran kooperatif berbasis gaya belajar peserta didik. Penelitian ini termasuk penelitian pengembangan. Yang dikembangkan adalah perangkat pembelajaran yang terditi atas (1) RPP; (2) LKPD; dan (3) Buku Ajar. Desain pengembangan perangkat yang digunakan mengacu pada model pengembangan Kemp dengan subjek penelitian adalah peserta didik kelas VIII SMP. Proses pengumpulan data menggunakan lembar validasi, lembar pengamatan, angket respon peserta didik, angket gaya belajar, dan tes hasil belajar fisika. Hasil penelitian menunjukkan bahwa perangkat pembelajaran yang dikembangkan merupakan perangkat pembelajaran yang baik karena telah memenuhi kriteria valid, praktis, dan efektif.
\end{abstract}

Kata kunci : pembelajaran kooperatif, gaya belajar

\section{PENDAHULUAN}

Pendidikan berhubungan erat dengan proses pembelajaran sehingga faktor-faktor di dalamnya akan sangat mempengaruhi hasil belajar peserta didik baik kualitas maupun kuantitas dalam nilai. Dalam proses pencapaiannya, hasil belajar dipengaruhi oleh berbagai faktor. Salah satu faktor yang dianggap mempengaruhi dalam hasil pembelajaran adalah gaya belajar [1].

Gaya belajar merupakan kunci untuk mengembangkan kinerja dalam pekerjaan di sekolah dan dalam situasi-situasi antar pribadi [2]. Peserta didik memiliki cara belajarnya sendiri sehingga dapat menyerap dan mengolah informasi yang diterimanya secara maksimal. Setiap individu memiliki cara belajar berbeda dengan yang lainnya.

Sebagian peserta didik lebih suka bila guru mereka mengajar dengan cara menuliskan semua materi ajar, dengan begitu mereka bisa membaca untuk kemudian mencoba memahaminya. Namun, sebagian yang lain lebih suka guru mereka mengajar dengan cara menyampaikannya secara lisan sambil mereka mendengarkan untuk dapat memahaminya. Sementara itu, ada peserta didik yang lebih suka membentuk kelompok kecil untuk mendiskusikan pertanyaan yang menyangkut pelajaran tersebut.

Penggunaan sumber belajar juga dapat menjadi salah satu faktor yang berpengaruh terhadap gaya belajar peserta didik. Ada peserta didik yang lebih suka sumber berupa audio, ada peserta didik yang lebih suka sumber berupa visual, dan ada juga yang belajar dengan mengerakkan seluruh anggota tubuh.

Berdasarkan uraian di atas, penulis bermaksud mengembangkan suatu perangkat pembelajaran dengan mengintegrasikan gaya belajar di dalamnya, agar peserta didik dapat mengoptimalkan potensi yang dimilikinya sebagai upaya dalam meningkatkan hasil belajarnya.

Untuk memenuhi maksud tersebut, perlu digunakan sebuah model pembelajaran untuk mengaktifkan peserta didik dalam berbagi informasi dan memanfaatkan segala potensi yang ada pada dirinya dalam membangun pengetahuannya. Model pembelajaran yang cocok untuk tujuan semacam ini adalah model pembelajaran kooperatif. Pembelajaran kooperatif merujuk pada berbagai macam metode pengajaran di mana para peserta didik bekerja dalam kelompok-kelompok kecil untuk saling membantu satu sama lainnya dalam mempelajari materi pelajaran [3].

Tujuan dibentuknya kelompok adalah untuk memberikan kesempatan kepada semua peserta didik untuk dapat terlibat secara aktif dalam proses berpikir dan/atau dalam kegiatan belajar. Manfaat penerapan belajar kooperatif adalah untuk mengurangi kesenjangan pendidikan khususnya dalam wujud input pada level individual [4].

Pembelajaran kooperatif menurut Ref. [5] dilaksanakan dengan langkah-langkah sebagai berikut: 
TABEL 1. LANGKAH PEMBELAJARAN KOOPERATIF

\begin{tabular}{|c|c|}
\hline Langkah-langkah & Perilaku Guru \\
\hline \begin{tabular}{lr}
\multicolumn{2}{l}{ Present goal and set } \\
Menyampaikan & tujuan \\
pembelajaran & dan \\
mempersiapkan & peserta \\
didik. & \\
\end{tabular} & $\begin{array}{lr}\text { Menjelaskan } & \text { tujuan } \\
\text { pembelajaran } & \text { dan } \\
\text { mempersiapkan } & \text { peserta } \\
\text { didik siap belajar } & \end{array}$ \\
\hline $\begin{array}{l}\text { Present information } \\
\text { Menyajikan informasi. }\end{array}$ & $\begin{array}{l}\text { Mempresentasikan informasi } \\
\text { kepada peserta didik secara } \\
\text { verbal }\end{array}$ \\
\hline $\begin{array}{l}\text { Organize students into } \\
\text { learning teams. } \\
\text { Mengorganisir } \\
\text { didik ke dalam tim-tim } \\
\text { belajar. }\end{array}$ & $\begin{array}{l}\text { Memberikan penjelasan } \\
\text { kepada peserta didik } \\
\text { tentang tata cara } \\
\text { pembentukan tim belajar } \\
\text { dan membantu kelompok } \\
\text { melakukan transisi yang } \\
\text { efisien. }\end{array}$ \\
\hline $\begin{array}{l}\text { Assist team work and } \\
\text { study. } \\
\text { Membantu kerja tim dan } \\
\text { belajar. }\end{array}$ & $\begin{array}{llr}\text { Membantu } & \text { tim-tim belajar } \\
\text { selama peserta didik } \\
\text { mengerjakan tugasnya }\end{array}$ \\
\hline $\begin{array}{l}\text { Test of materials } \\
\text { Mengevaluasi }\end{array}$ & $\begin{array}{l}\text { Menguji pengetahuan } \\
\text { peserta didik mengenai } \\
\text { materi pembelajaran atau } \\
\text { kelompok-kelompok } \\
\text { mempresentasikan hasil } \\
\text { kerjanya }\end{array}$ \\
\hline $\begin{array}{l}\text { Provide recognition. } \\
\text { Memberikan pengakuan } \\
\text { atau penghargaan. }\end{array}$ & $\begin{array}{l}\text { Mempersiapkan cara untuk } \\
\text { mengakui usaha dan } \\
\text { prestasi individu maupun } \\
\text { kelompok }\end{array}$ \\
\hline
\end{tabular}

Hasil Penelitian Ref. [6] menunjukkan bahwa interaksi antara model pembelajaran kooperatif dengan gaya belajar dapat mempengaruhi hasil belajar siswa pada materi pokok ikatan kimia di kelas X SMK Negeri 2 Bantaeng.

Dengan menerapkan pembelajaran kooperatif yang mengintegrasikan gaya belajar di dalamnya, diharapkan peserta didik dengan gaya belajar yang berbeda dapat saling membantu dalam belajar.

\section{METODE PENELITIAN}

Penelitian ini merupakan penelitian pengembangan. Adapun yang dikembangkan dalam penelitian ini adalah perangkat pembelajaran yang meliputi: RPP, LKPD, dan buku ajar.

Pengembangan perangkat ini mengacu pada model perancangan pengembangan sistem pembelajaran menurut Kemp. Bentuk desainnya disajikan pada Gambar 1 berikut:

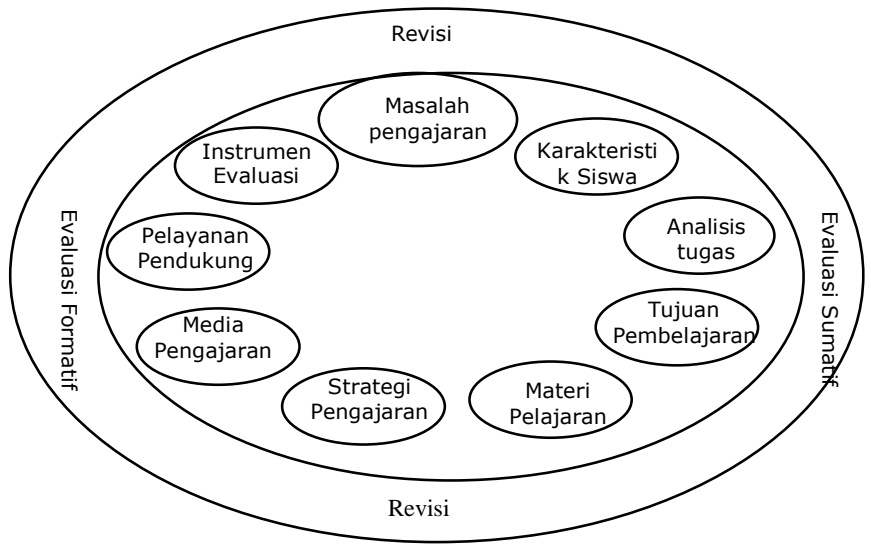

Gbr 1. Siklus pengemb. sistem pembel. yang diadopsi dari model Kemp [7].

Uji coba perangkat dilaksanakan di SMP Negeri 1 Sendana dengan subjek penelitian adalah peserta didik kelas VIII.

\section{HASIL DAN PEMBAHASAN}

Gambaran hasil penelitian ini diuraikan sebagai berikut.

\section{Deskripsi Tahap Pengembangan}

Pengembangan perangkat pembelajaran kooperatif berbasis gaya belajar dalam penelitiaan ini menggunakan model pengembangan Kemp dengan prosedur dideskripsikan seperti berikut ini.

\section{a. Identifikasi Masalah Pembelajaran}

Berdasarkan fenomena di lapangan, masalah esensial yang perlu mendapatkan perhatian dalam hal pembelajaran di sekolah tersebut adalah:

1) Terbatasnya sumber belajar yang digunakan dalam pembelajaran.

2) Materi pembelajaran tidak dikemas menyesuaikan kondisi peserta didik sebab berpatokan pada buku paket yang ada sehingga terkesan monoton dan memaksa peserta didik untuk berbuat sesuai apa yang diperintahkan oleh guru.

3) Masih kurangnya kegiatan peserta didik dalam percobaan fisika yang dapat menunjang penguasaan konsep fisika.

4) Metode pembelajaran yang sering digunakan adalah metode ceramah yang disertai latihan soal dan pemberian tugas, sedangkan untuk metode yang lain misalnya demonstrasi, diskusi, eksperimen, dan sebagainya jarang dilakukan karena keterbatasan alat-alat di laboratorium. 


\section{b. Analisis Karakteristik Peserta Didik}

Berdasarkan hasil observasi dan wawancara dengan pihak sekolah, yaitu guru bidang studi fisika, maka diperoleh beberapa karakteristik peserta didik, yang meliputi:

1) Rata-rata usia peserta didik yang menjadi subyek penelitian adalah 12 tahun ke atas.

2) Peserta didik kelas memiliki kemampuan beragam, yaitu kemampuan akademik: tinggi, sedang, dan rendah.

3) Peserta didik memiliki gaya belajar yang berbeda. Ada yang visual, auditori, dan kinestetik.

4) Peserta didik memiliki latar belakang suku yang sama. Bahasa sehari-hari mereka adalah bahasa daerah dan bahasa Indonesia hanya digunakan saat pembelajaran di kelas.

Berdasarkan karakteristik di atas, maka peserta didik kelas VIIIB yang menjadi subjek penelitian termasuk heterogen, jika dilihat dari kemampuan akademik dan gaya belajarnya.

\section{c. Analisis Tugas}

Analisis tugas dilakukan untuk mengedintifikasi tahap-tahap penyelesaian tugas sesuai dengan bahan kajian materi. Analisis tugas ini meliputi analisis materi pelajaran. Pada analisis materi dilakukan identifikasi konsep utama yang diajarkan, menyusun secara sistematis dan merinci konsep-konsep yang relevan. Materi yang dibahas dalam penelitian ini terletak pada standar kompetensi (SK 5) yaitu memahami peranan usaha, gaya, dan energi dalam kehidupan sehari-hari dengan kompetensi dasar (KD 5.5) menyelidiki tekanan pada benda padat, cair, dan gas serta penerapannya dalam kehidupan sehari-hari.

Hasil akhir analisis tugas adalah tertuang dalam Buku Ajar dan Lembar Kerja Peserta Didik yang berpedoman pada kurikulum KTSP mata pelajaran IPA Fisika kelas VIII sebagai perangkat pembelajaran yang digunakan dalam penelitian.

Analisis proses informasi bertujuan untuk mengelompokkan tugas yang harus dilaksanakan oleh peserta didik pada setiap kali pertemuan. Dari hasil analisis ini dapat diketahui konsep dan tujuan mana yang disajikan pada pertemuan 1, 2 dan seterusnya.

\section{d. Perumusan Indikator}

Berdasarkan analisis konsep maka spesifikasi indikator pembelajaran yang mengacu pada kompetensi dasar pada materi tekanan adalah:
1) Menemukan hubungan antara gaya, tekanan, dan luas daerah yang dikenai gaya melalui percobaan.

2) Menemukan faktor-faktor yang mempengaruhi tekanan pada zat padat.

3) Menyelidiki hubungan antara tekanan, massa jenis dan kedalaman suatu zat cair.

4) Mengidentifikasi aplikasi prinsip bejana berhubungan dalam kehidupan sehari-hari.

5) Mendeskripsikan hukum Pascal melalui demonstrasi sederhana serta penerapannya dalam kehidupan seharihari.

6) Menjelaskan contoh aplikasi hukum pascal dalam kehidupan sehari-hari.

7) Mendeskripsikan hukum Archimedes melalui percobaan sederhana serta penerapannya dalam kehidupan seharihari.

8) Menjelaskan produk teknologi dalam kehidupan sehari-hari sehubungan dengan konsep benda terapung, melayang, dan tenggelam.

9) Menyelidiki pengaruh suhu terhadap tekanan udara.

10) Mengidentifikasi contoh pemanfaatan tekanan udara dalam kehidupan seharihari.

Keseluruhan indikator pembelajaran tersebut menjadi acuan dalam merancang perangkat pembelajaran yang dikembangkan dalam penelitian ini.

\section{e. Penyusunan Alat Evaluasi}

Berdasarkan analisis peserta didik, analisis konsep dan perumusan indikator, selanjutnya disusun alat evaluasi dalam hal ini tes hasil belajar.

Tes tersebut divalidasi terlebih dahulu dengan meminta pertimbangan atau judgement dari dua orang ahli. Setelah dilakukan revisi berdasarkan saran validator, selanjutnya tes diujicobakan kepada peserta didik kelas VIII SMPN 1 Sendana untuk melihat validitas butir soal dan reliabilitasnya sebelum digunakan sebagai pretest.

\section{f. Pemilihan Strategi Pembelajaran}

Berdasarkan hasil identifikasi masalah dan hasil analisis peserta didik, maka dilakukan pemilihan strategi pembelajaran yang sesuai dengan tujuan, dimana dalam hal ini peneliti memilih pembelajaran kooperatif berbasis gaya belajar untuk diterapkan pada pembelajaran pokok bahasan Tekanan. 
Pembelajaran kooperatif berbasis gaya belajar merupakan suatu strategi pengajaran dimana peserta didik dibagi ke dalam kelompok-kelompok yang disusun secara heterogen berdasarkan kemampuan akademik dan gaya belajar mereka. Dalam satu kelompok selain terdapat peserta didik yang berbeda tingkat kemampuan akademiknya, juga terdapat peserta didik yang berbeda jenis gaya belajarnya. Hal ini dimaksudkan agar setiap peserta didik dalam kelompok dapat bekerjasama dan saling melengkapi sehingga dapat memaksimalkan hasil belajar mereka.

\section{g. Pemilihan Media Pembelajaran}

Pemilihan media dilakukan untuk menentukan media yang sesuai untuk menyajikan materi pembelajaran. Adapun media yang digunakan dalam pembelajaran pada penelitian ini adalah: Papan tulis, LCD, Buku Ajar, LKPD. Sedangkan alat-alat dan bahan yang digunakan dalam pengamatan/demonstrasi seperti: barometer, bejana berhubungan, botol plastik, alat suntik, serta alat dan bahan yang tercantum pada LKPD.

\section{h. Fasilitas Pendukung}

Fasilitas pendukung sangat menunjang keberhasilan penelitian. Dalam hal ini berupa laboratorium. Ruangan laboratorium yang terdapat pada SMPN 1 Sendana tergolong baik. Selain itu, untuk menunjang keberhasilan penelitian juga diperlukan guru mitra. Guru mitra tersebut berfungsi sebagai observer dalam proses penilaian pembelajaran.

\section{i. Evaluasi}

Pada tahap ini dilakukan evaluasi, berupa pemberian tes hasil belajar (post-test) yang bertujuan memberikan informasi kepada peneliti tingkat penguasaan peserta didik terhadap materi yang telah diajarkan dan tingkat pencapaian peserta didik terhadap tujuan-tujuan pembelajaran.

\section{j. Revisi Perangkat Pembelajaran}

Revisi dilakukan secara terus-menerus pada setiap langkah pengembangan. Kegiatan ini dimaksudkan untuk mengevaluasi dan memperbaiki rancangan yang dibuat. Revisi awal diperoleh dari kegiatan validasi perangkat pembelajaran oleh pakar sehingga validasi ini lebih pada tujuan kebenaran dan kesesuaian isi pada saat menerapkannya pada pembelajaran di sekolah. Pada saat uji coba, revisi dilakukan pada tiap kali pertemuan yaitu dengan melakukan perbaikan-perbaikan terhadap kekurangan yang terjadi pada proses pembelajaran di pertemuan sebelumnya.

\section{Deskripsi Hasil Pengembangan}

a. Validasi Perangkat Pembelajaran

Salah satu kriteria utama untuk menentukan apakah sebuah perangkat pembelajaran dapat dipakai atau tidak adalah hasil validasi ahli. Penilaian para ahli umumnya berupa catatancatatan kecil pada bagian yang perlu perbaikan.

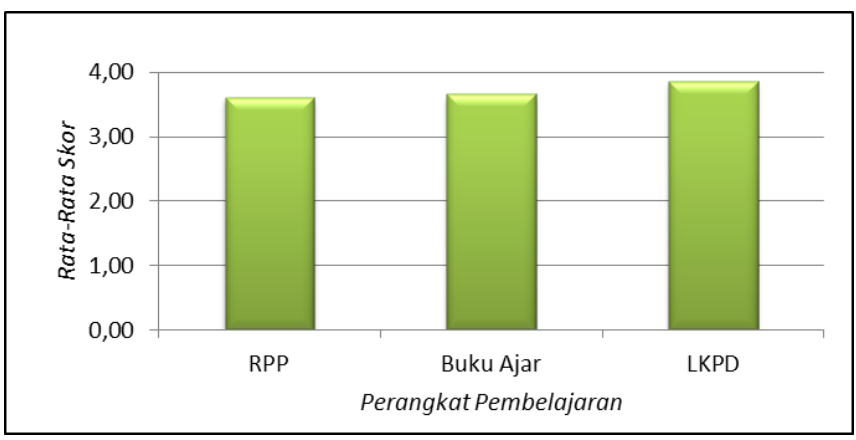

Gbr 2. Diagram hasil validasi perangkat pembelajaran kooperatif berbasis gaya belajar.

Rata-rata kevalidan RPP berada pada kategori sangat valid. Meskipun demikian, ada beberapa saran dari ahli yang perlu diperhatikan sekaligus sebagai revisi perangkat RPP untuk kesempurnaan dalam penggunaannya dalam uji coba di lapangan

\section{b. Hasil Uji Coba}

1) Hasil Analisis Gaya Belajar Peserta Didik

Untuk mengetahui gaya belajar peserta didik, mereka diberikan angket yang berisi beberapa pernyataan. Angket ini diberikan kepada seluruh peserta didik kelas VIIIB sebelum mengikuti proses pembelajaran.

Data dari angket gaya belajar peserta didik ini kemudian dianalisis sehingga diperoleh hasil seperti yang diperlihatkan pada diagram di bawah ini.

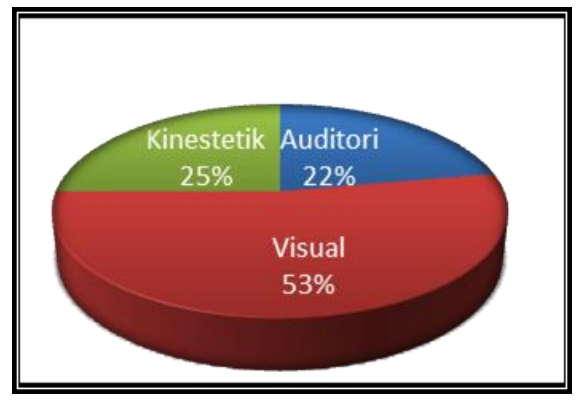

Gbr 3. Diagram persentase gaya belajar peserta didik. 
Dari tabel diatas, terlihat bahwa peserta didik kelas VIIIB SMPN 1 Sendana memiliki gaya belajar berbeda.

2) Hasil Pengamatan Keterlaksanaan Perangkat Pembelajaran

Tujuan utama analisis data keterlaksanaan perangkat pembelajaran adalah untuk melihat sejauh mana tingkat keterlaksanaan perangkat dalam proses pembelajaran. Data pengamatan keterlaksanaan perangkat pembelajaran diperoleh melalui observasi yang dilakukan oleh tiga orang pengamat.

Hasil observasi terhadap keterlaksanaan perangkat pembelajaran dari 5 kali pertemuan, dirangkum dalam diagram berikut:

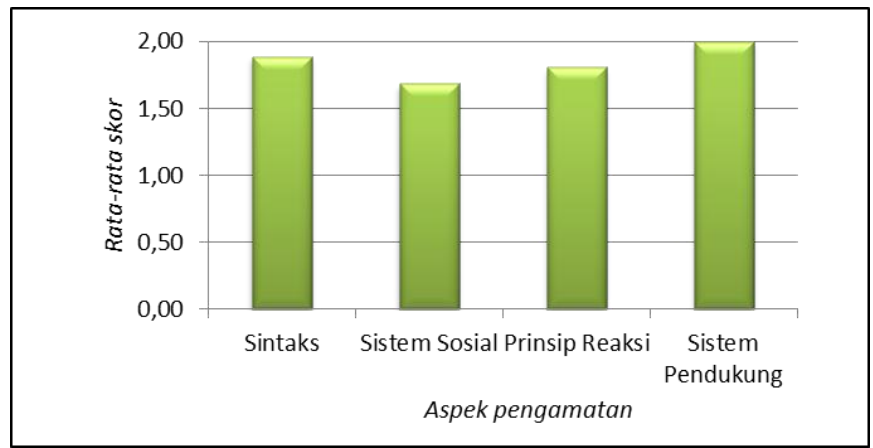

Gbr 4. Diagram hasil pengamatan keterlaksanaan perangkat pembelajaran

Terlihat bahwa keterlaksanaan perangkat pembelajaran berada pada rata-rata $\mathrm{M}=1,85$ yang menunjukkan bahwa semua komponen yang diamati terlaksana seluruhnya $(1,5 \leq \mathrm{M} \leq$ $2,0)$ dengan koefisien reliabilitas 0,89 .

\section{3) Hasil Pengamatan Pengelolaan \\ Pembelajaran}

Analisis data pengelolaan pembelajaran dilakukan untuk melihat kemampuan guru dalam mengelola proses pembelajaran. Data pengelolaan pembelajaran diperoleh melalui observasi yang dilakukan oleh tiga orang pengamat.

Hasil observasi terhadap pengelolaan pembelajaran selama 5 kali pertemuan, dirangkum dalam diagram di bawah ini.

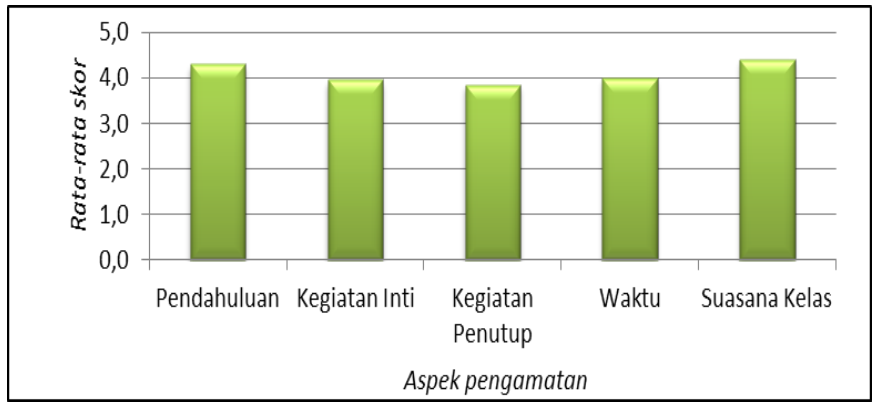

Gbr 5. Diagram hasil pengamatan pengelolaan pembelajaran

\section{4) Respon Peserta Didik}

Analisis respon peserta didik meliputi respon peserta didik terhadap proses pembelajaran dan perangkat pembelajaran yang dituangkan dalam angket respon peserta didik.

Hasil analisis data respon peserta didik terhadap perangkat dan pelaksanaan pembelajaran ditunjukkan pada diagram dibawah ini.

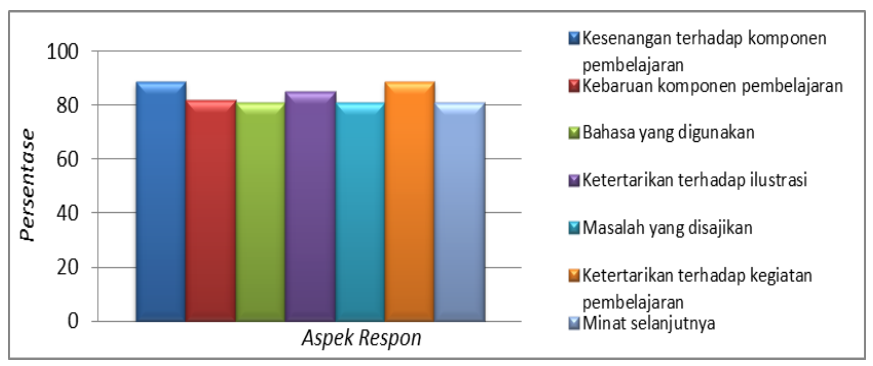

Rata-rata respon peserta didik terhadap perangkat dan proses pembelajaran yaitu $84 \%$. Berdasarkan kriteria yang telah ditentukan, maka dapat disimpulkan bahwa respon peserta didik terhadap perangkat dan proses pembelajaran umumnya memberikan respon sangat baik (81 \% - $100 \%)$. Hal ini dapat dilihat grafik berikut:

\section{Pembahasan}

Perangkat pembelajaran yang baik, setidaknya ada tiga kriteria yang harus dimiliki yaitu valid, praktis, dan efektif. Dengan bantuan model pembelajaran kooperatif berbasis gaya belajar maka kriteria tersebut dapat diuraikan sebagai berikut:

\section{a. Valid}

Hasil penilaian diperoleh bahwa komponen perangkat pembelajaran memiliki nilai rata-rata yang umumnya berada pada kategori sangat valid. Ini berarti bahwa ditinjau dari aspek penilaian ahli maka perangkat pembelajaran kooperatif berbasis gaya belajar yang 
dikembangkan telah memenuhi kriteria kevalidan, namun masih terdapat saran-saran perbaikan yang perlu diperhatikan untuk kesempurnaan perangkat yang dikembangkan, yaitu meliputi: (1) harus dapat menampakkan unsur-unsur pembelajaran kooperatif berbasis gaya belajar agar ada ciri khusus yang membedakan dengan perangkat pembelajaran yang lain; (2) tingkat keterbacaan serta bahasanya agar disesuaikan dengan tingkat pemahaman peserta didik; dan (3) perangkat yang disusun tetap harus memperhatikan indikator serta tujuan pembelajaran yang ingin dicapai. Setelah dilakukan revisi maka perangkat pembelajaran ini dapat digunakan.

\section{b. Praktis}

Praktisnya perangkat pembelajaran yang dikembangkan, selain dapat dilihat dari kevalidan perangkat tersebut, juga dapat didasarkan pada tingkat keterlaksanaan perangkat dalam proses pembelajaran. Sebagaimana telah diuraikan sebelumnya bahwa hasil penilaian validator tentang perangkat pembelajaran kooperatif berbasis gaya belajar dinyatakan telah memenuhi kriteria kevalidan dan telah layak digunakan.

Hasil uji coba di kelas diperoleh nilai ratarata keterlaksanaan perangkat pembelajaran kooperatif berbasis gaya belajar adalah $\mathrm{M}=$ 1,85 . Berdasarkan kriteria penilaian yang telah disebutkan sebelumnya, nilai rata-rata tersebut berada pada kategori terlaksana seluruhnya. Dengan demikian dapat disimpulkan bahwa perangkat pembelajaran ini telah memenuhi syarat kepraktisan.

Hal ini menunjukkan bahwa peneliti mampu melaksanakan setiap fase pembelajaran kooperatif berbasis gaya belajar dengan baik. Selain itu, hal ini juga menunjukkan bahwa perangkat yang dikembangkan mampu membantu peserta didik dengan gaya belajar yang berbeda saling berinteraksi, sehingga antara peserta didik yang satu dengan yang lainnya dapat untuk saling melengkapi dan bertukar pengetahuan tentang materi yang diajarkan. Dari segi kepraktisannya, perangkat pembelajaran sangat praktis digunakan karena telah merinci kegiatan-kegiatan yang dilakukan oleh peserta didik dan guru dengan bahasa yang jelas dan mudah dipahami. Selain itu masalah yang ditampilkan bersifat kontekstual sehingga dapat menarik minat peserta didik untuk belajar.

Hal di atas sesuai dengan pendapat yang dikemukakan oleh Gagne, bahwa pembelajaran yang dipersiapkan dengan matang sesuai dengan langkah-langkah yang benar akan menghasilkan suatu perangkat pembelajaran yang baik. Dalam rangka pembelajaran, guru dapat menyusun acara pembelajaran yang cocok dengan tahap dan fase-fase belajar. Pola hubungan antara fase belajar dan kegiatan pembelajaran dapat dijadikan pedoman pelaksanaan pembelajaran di kelas dan sudah barang tentu guru masih harus menyesuaikan dengan bidang studi dan kondisi kelas yang sebenarnya.

\section{c. Efektif}

Perangkat pembelajaran kooperatif berbasis gaya belajar yang dikembangkan dapat dikatakan efektif jika memenuhi beberapa kriteria yaitu: (1) minimal $85 \%$ dari seluruh peserta didik dinyatakan tuntas, (2) kemampuan guru dalam mengelola pembelajaran berada dalam kategori tinggi, dan (3) respon peserta didik terhadap perangkat pembelajaran dan proses pembelajaran berada pada kategori positif.

\section{1) Hasil belajar fisika}

Perangkat pembelajaran yang dikembangkan dikatakan bermanfaat atau efektif dalam membantu penguasaan materi peserta didik jika minimal $85 \%$ dari seluruh peserta didik di kelas memenuhi kriteria ketuntasan minimal (KKM) yaitu 63.

Berdasarkan hasil analisis data diperoleh bahwa nilai rata-rata hasil belajar fisika peserta didik setelah mengikuti pembelajaran kooperatif berbasis gaya belajar adalah 70,9.

Selanjutnya berdasarkan tingkat ketercapaian KKM diperoleh bahwa terdapat 5 orang atau sekitar $13,9 \%$ peserta didik kelas VIIIB yang belum mencapai kriteria KKM. Hal ini berarti bahwa pelajaran dianggap tuntas karena lebih dari $85 \%$ peserta didik telah mencapai standar KKM. Jika dilihat ketuntasannya berdasarkan gaya belajarnya, jumlah peserta didik dengan gaya belajar auditori $100 \%$ tuntas, kinestetik $100 \%$ tuntas, sedangkan untuk peserta didik dengan gaya belajar visual $78,95 \%$ tuntas. Dengan demikian, dapat dikatakan bahwa perangkat pembelajaran kooperatif berbasis gaya belajar yang dikembangkan, secara efektif mempengaruhi penguasaan materi peserta didik dengan gaya belajar yang berbeda, yang ditandai peningkatan hasil belajarnya. Hasil ini juga didukung dengan data hasil pengukuran psikomotor peserta didik. 
2) Kemampuan mengelola pembelajaran Keberhasilan guru dalam mengelola pelaksanaan pembelajaran mengacu pada terlaksananya setiap fase yang telah ditetapkan dalam RPP dan kemampuan mentransfer pembelajaran dengan baik sehingga menimbulkan respon positif peserta didik terhadap proses pembelajaran.

Proses pembelajaran di kelas yakni, guru mengawali pembelajaran dengan menyampaikan tujuan pembelajaran yang akan dicapai dan memotivasi peserta didik dengan mengajak peserta didik untuk melakukan demostrasi. Setelah guru menyampaikan sedikit informasi mengenai materi pelajaran secara audio (ceramah) dan visual (presentasi), kemudian guru mengorganisir peserta didik ke dalam kelompok kooperatif berbasis gaya belajar. Selanjutnya peserta didik diarahkan untuk melakukan kegiatan yang bersifat kinestetis (eksperimen) sesuai LKPD yang dibagikan. Selama peserta didik bekerja dalam kelompok, guru membimbing peserta didik untuk berdiskusi agar terjadi penyebaran pengetahuan antara peserta didik dengan gaya belajar yang berbeda. Apabila ada peserta didik atau kelompok yang mengalami kesulitan maka guru membimbing mereka dengan memberikan arahan atau contoh mengenai hal-hal yang mereka kurang mengerti.

Setelah peserta didik selesai mengerjakan LKPD, maka fase berikutnya adalah guru membantu peserta didik menyajikan hasil karya. Guru mempersilahkan wakil dari beberapa kelompok untuk memaparkan hasil yang diperolehnya, dan kelompok lainnya menanggapi sementara guru bertindak sebagai fasilitator. Guru memberikan refleksi berupa pemberian penghargaan kepada kelompok sesuai peringkat yang diperolehnya. Dan sebagai akhir dari proses pembelajaran, guru beserta peserta didik menarik kesimpulan dari materi yang telah diajarkan.

Hasil pengamatan oleh tiga orang pengamat menunjukkan bahwa setiap fase dapat dilaksanakan oleh guru dengan baik dan ratarata kemampuan guru dalam mengelola pembelajaran berada pada kategori tinggi. Adapun kekurangan yang tampak pada pertemuan sebelumnya, dilakukan evaluasi dan perbaikan pada pertemuan berikutnya.

\section{3) Respon peserta didik}

Respon peserta didik terhadap perangkat pembelajaran dan proses pembelajaran diperoleh setelah peserta didik melalui proses pembelajaran menggunakan perangkat pembelajaran kooperatif berbasis gaya belajar. Adapun hasil yang diperoleh yaitu lebih dari $80 \%$ dari keseluruhan peserta didik memberikan respons baik. Artinya, secara umum perangkat pembelajaran yang dikembangkan serta pelaksanaan proses pembelajaran sudah mampu diterima dengan baik oleh peserta didik.

\section{KESIMPULAN}

Berdasarkan hasil penelitian yang telah dilakukan, dapat disimpulkan bahwa perangkat pembelajaran yang dihasilkan dalam penelitian ini meliputi: (1) Rencana Pelaksanaan Pembelajaran, (2) Buku Ajar, dan (3) Lembar Kegiatan Peserta Didik, dan (4) Instrumen evaluasi, merupakan perangkat pembelajaran yang baik karena telah memenuhi kriteria valid, praktis, dan efektif.

\section{DAFTAR PUSTAKA}

[1]. Nurmayani. 2016. Pengaruh Gaya Belajar VAK pada Penerapan Model Pembelajaran Problem Based Learning Terhadap Hasil Belajar IPA Fisika Siswa SMP Negeri 2 Narmada Tahun Ajaran 2015/2016. Jurnal Pendidikan Fisika dan Teknologi, Volume II No. 1, Januari 2016

[2]. DePorter, Bobbi \& Hernacki, Mike. 2003. Quantum Learning (Terjemahan). Bandung: Kaifa.

[3]. Trianto. 2009. Mendesain Model Pembelajaran Inovatif-Progresif: Konsep, Landasan, dan Implementasinya pada Kurikulum Tingkat Satuan Pendidikan (KTSP). Jakarta: Kencana Prenada Media Group.

[4]. Slavin, Robert E. 2008. Cooperative Learning: Teori, Riset dan Praktik. Bandung: Nusa Media.

[5]. Suprijono, Agus. 2009. Cooperative Learning: Teori dan Aplikasi Paikem. Yogyakarta: Pustaka Pelajar.

[6]. Ahriani, Faridha. 2013. Pengaruh Model Pembelajaran Kooperatif dan Gaya Belajar Terhadap Hasil Belajar Kimia Peserta Didik Kelas X SMK Negeri 2 Bantaeng. Jurnal Chemica Vol. 14 Nomor 1, Juni 2013.

[7]. Kemp, E.J., Morrison, R.G., and Ross, M.S. 1994. Designing Effective Instruction. New York. Macmillan College Publishing Company. 